\title{
KEMAMPUAN MEMPREDIKSI PESERTA DIDIK DALAM FISIKA TINGKAT SMA DI KOTA MAKASSAR
}

\author{
Herman Anis ${ }^{\text {a) }}$, Bunga Dara Amin ${ }^{\text {b) }}$, Kaharuddin Arafah' ${ }^{\text {c) }}$ \\ Prodi Pendidikan Fisika Fakultas MIPA Universitas Negeri Makassar \\ Email: a)herman@unm.ac.id , b) bungadaraamin@unm.ac.id , ${ }^{\mathrm{c}}$ kahar.arafah@unm.ac.id
}

\begin{abstract}
Abstrak
Tulisan ini merupakan hasil penelitian deskriptif kuantitatif pada peserta didik kelas XI semester genap Tahun Akademik 2018/2019 di Kota Makassar yang berjumlah 103 orang. Pemilihan sampel dilakukan dengan teknik proportional-cluster random sampling. Data penelitian diperoleh melalui instrumen tes berbentuk uraian. Hasil penelitian menunjukkan kemampuan peserta didik dalam memprediksi berdasarkan data dari grafik berada pada kategori rendah. Dengan demikian maka dapat disimpulkan bahwa kemampuan peserta didik memprediksi dalam fisika di Kota Makassar 2018/2019 rendah.
\end{abstract}

Kata-kata kunci: kemampuan, memprediksi.

\begin{abstract}
This study was descriptive quantitative which was done to XI grade student in 2018/2019 academic year. Study subject was 103 student which were chosen by proportional-cluster random sampling method. The study data were collected by using descriptive testing instrument. The study result shows that student predicting ability for data from graphics is in poor category. This study result generates a conclusion that student's physics predicting ability in 2018/2019 is poor.
\end{abstract}

Keywords: ability, predicting.

\section{PENDAHULUAN}

Penerapan Kurikulum 2013 merupakan salah satu upaya pemerintah untuk meningkatkan kualitas sumber daya manusia khusnya melalui pendidikan di tingkat sekolah. Dalam Kurikulum 2013 peserta didik diharapkan mampu menjadi insan Indonesia yang produktif, kreatif, inovatif, dan afektif melalui penguatan sikap (tahu mengapa), keterampilan (tahu bagaimana), dan pengetahuan (tahu apa) yang terintegrasi. Dengan demikian maka dalam kurikulum 2013, pembelajaran di kelas harus dapat mendorong siswa untuk memiliki kemampuan yang lebih baik dalam melakukan pengamatan, mengajukan pertanyaan, melakukan penalaran, dan mengomunikasikan (mempresentasikan) melalui proses belajarnya. Untuk mewujudkan hal tersebut, maka diperlukan pembelajaran yang berbasis pada sains, atau yang lebih dikenal dengan pendekatan scientific.

Pendekatan scientific merupakan proses pembelajaran yang dilaksanakan dengan dipandu skorskor, prinsip-prinsip, atau kriteria ilmiah. Pendekatan scientific dalam proses pembelajaran sains dapat diterapkan melalui keterampilan proses sains (KPS). Keterampilan proses sains merupakan seperangkat keterampilan yang digunakan para ilmuwan dalam melakukan penyelidikan ilmiah. Oleh 
karena itu, proses pembelajaran dalam Kurikulum 2013 mengacu pada proses ilmiah atau juga bisa disebut sebagai keterampilan proses sains.

Prodi pendidikan fisika sebagai salah satu LPTK penghasil guru/tenaga pendidik harus mempersiapkan lulusannnya untuk dapat menerapkan kurikulum 2013 tersebut dengan baik. Untuk itu, diperlukan langkah-langkah strategis dari Prodi Pendidikan Fisika untuk menjawab tuntutan jaman yang terus berkembang. Hasil post test (UTN) mahasiswa angkatan IV PPG SM3T prodi pendidikan fisika pada tahun 2016, pada tes pertama, dari 18 orang peserta hanya dua orang yang dinyatakan lulus, atau sekitar 89 persen gagal. Hal ini menjadi bahan renungan dan evaluasi, meskipun peserta dari PPG SM3T bukan hanya berasal dari prodi pendidikan fisika UNM, namun ada dari luar UNM. Hasil analisis terhadap soal-soal UTN dan diskusi dengan peserta PPG SM3T peneliti berkesimpulan bahwa soal-soal yang susah diselesaikan adalah soal-soal yang isinya berupa sajian data, grafik, yang kemudian mempertanyakan besaran fisika yang dapat diperoleh/dianalisis dari data/grafik yang disajikan. Beberapa soal yang dikaji, menunjukkan bahwa sebagian peserta belum pernah mendapatkan soal-soal dalam bentuk tersebut, baik dalam bangku kuliah maupun dalam proses pembelajaran pada saat PPG SM3T. Berdasarkan hal tersebut peneliti berpendapat bahwa yang menjadi permasalahan peserta adalah kemampuan mereka dalam keterampilan proses sains (KPS).

Sejalan dengan hal di atas hasil analisis Ujian Nasional (UN) khususnya bidang fisika di Kabupaten Jeneponto dan Kabupaten Takalar pada tahun 2010 menunjukkan bahwa peserta didik mengalami kesulitan dalam menyelesaikan menyelesaikan soal-soal yang berisi TABEL data dan grafik/kurva. Dari dua Kabupaten tersebut persentase rata-rata peserta didik yang menjawab benar masing-maisng sekitar $19 \%$ dan 24\%. Peserta didik mengalami masalah/kesulitan dalam menyelesaikan soal tersebut oleh karena keterampilan/pengetahuan dalam menganalisis data, menafsirkan data, dan menginterpretasi data kurang/rendah. Faktor yang dapat menjadi penyebabnya adalah kurang terbiasanya peserta didik dengan pembelajaran yang berisi kegiatan yang melibatkan keterampilan proses sains [1].

Beberapa hasil penelitian lain menunjukkan bahwa keterampilan proses sains di Indonesia memang belum menggembirakan. Hal ini dapat dilihat sebagai berikut: (a) hasil penelitian Nur dkk, menunjukkan bahwa nilai rata-rata keterampilan proses sains SMA Al Hikmah Surabaya mengidentifikasi pernyataan tentang pengamatan $(0,39)$, inferensi $(0,42)$, prediksi $(0,43)$, klasifikasi $(0,47)$, model $(0,55)$, hipotesis $(0,54)$, mengidentifikasi variabel dependen dari suatu eksperimen $(0,13)$, (b) hasil penelitian Triwiyono di SMP Jayapura menunjukkan rata-rata persentase kemampuan siswa mengkomunikasikan dan membuat inferensi sebesar $52 \%$, (c) hasil penelitian Widayanto menunjukkan bahwa perolehan nilai rata-rata persentase keterampilan proses sains siswa SMA N 3 Sragen, yaitu observasi, mengklasifikasi, memprediksi, menyimpulkan, mengidentifikasi variabel, membuat TABEL, membuat grafik, menganalisis variabel, menyusun hipotesis, mengukur, dan merancang eksperimen sebesar 48,66\%. Jadi dari beberapa hasil penelitian yang dilaksanakan di Indonesia, secara konsisten menunjukkan keterampilan proses sains peserta didik belum optimal [2].

Selain itu, kegiatan ilmiah dalam K-13 dioperasionalkan melalui pendekatan scientific atau yang lebih umum dikenal sebagai pendekatan KPS. KPS dicirikan oleh aktivitas eksperimen atau praktikum di laboratorium. Aktivitas ini menghasilkan data hasil pengukuran variabel fisis yang disajikan dalam bentuk TABEL. TABEL hasil pengamatan ini kemudian disajikan dalam bentuk grafik. Melalui grafik, karakteristik besaran yang diselidiki/dianalisis. Melalui grafik ilmuwan dapat melakukan prediksi berdasarkan pola-pola yang diperoleh.

Berdasarkan hal tersebut, penting untuk memahami fungsi grafik khususnya dalam sains. Grafik merupakan jenis representasi yang berguna dalam merangkum data, mengolah dan menafsirkan informasi baru dari data yang lebih kompleks. Melalui grafik, maka penjelasan yang panjang mampu diilustrasikan menjadi informasi yang singkat [3]. Penggunaan grafik dalam menjelaskan konsep dan hubungan antara konsep menjanjikan lebih banyak keberhasilan dan pembelajaran yang lebih bermakna dalam dunia sains [4]).

Christian dkk [5], dalam penelitiannya mengemukakan bahwa meskipun menggambar dan membaca grafik merupakan keterampilan yang nampaknya sepele namun masih ditemukan kesalahan-kesalahan mendasar. Kesalahan dalam menggambarkan grafik terjadi jika grafik tersebut 
dikaitkan dengan suatu konsep. Dalam penggambaran grafik posisi terhadap waktu dari sebuah pengamatan gerak ditemukan bahwa mahasiswa sering melakukan kesalahan dalam menggambarkan grafik benda dalam keadaan diam, benda yang bergerak dengan kecepatan tetap ketika menjauh dan kemudian kembali ke titik acuan. Kesalahan itu terjadi karena mahasiswa mendemontrasikan gerak yang diamati langsung pada grafik secara spasial tanpa memperhatikan sumbu waktu. Kesalahan ini berpotensi menghambat mahasiswa dalam memahai konsep-konsep abstrak yang direpresentasikan dalam bentuk grafik.

Petrova [6] dalam penelitiannya mengungkapkan bahwa banyak fakta yang ditemukan dimana peserta didik pada sekolah menengah bahkan mahasiswa di tingkat universitas masih memiliki kemampuan yang rendah dalam memahami arti fisis dari grafik yang disajikan. Hal ini menyebabkan mereka cenderung sulit untuk melakukan interpretasi. Beberapa penelitian lain juga mengungkapkan rendahnya kemampuan siswa dalam menginterpretasikan grafik, diantaranya adalah hasil penelitian. Selain itu, hasil penelitian Uzun, dkk [7] menemukan bahwa siswa mengalami kesulitan dalam membaca, menafsirkan dan memahami informasi yang tergambar dalam grafik.

Berdasarkan beberapa pendapat sebelumnya penulis berpandangan bahwa kemampuan peserta didik dalam menginterpretasi grafik merupakan salah satu kemampuan yang penting untuk mendapat perhatian dari guru ataupun pemerhati pendidikan. Oleh karena dengan kemampuan menginterpretasi grafik yang baik peserta didik dapat mengetahui hubungan antara besaran, mencari besaran lain dari grafik yang disajikan, dan yang lebih kompleks adalah kemampuan memprediksi berdasarkan grafik yang disajikan. Untuk itulah penulis secara khusus melakukan penelitian untuk mengkaji kemampuan peserta didik kelas XI MIPA Sekolah Menengah Atas (SMA) di Kota Makassar dalam menginterpretasi grafik khususnya pada kemampuan memprediksi berdasarkan grafik. Hal ini penulis lakukan untuk memperoleh gambaran kemampuan melakukan prediksi dan mengidentifikasi kesalahan-kesalahan peserta didik dalam melakukan prediksi. Penulis membatasi sasaran kajian dengan mengambil indikator memprediksi yakni menemukan pola matematis berdasarkan data/grafik hubungan antara variabel untuk memprediksi nilai suatu variabel.

\section{METODOLOGI}

Penelitian ini merupakan penelitian survey. Populasi dalam penelitian ini adalah seluruh peserta didik kelas X SMA/MA di Kota Makassar. Pengambilan sampel menggunakan teknik proportionalcluster random sampling. Peserta didik diambil secara acak dari 3 Sekolah yaitu, SMA N 9 Makassar, SMA N 10 Makassar dan MAN 11 Makassar dengan total peserta didik adalah 103 orang.

Variabel dalam penelitian ini variabel tunggal yaitu kemampuan mempediksi dalam fisika peserta didik kelas XI SMA/MA di Kota Makassar. Data penelitian di peroleh melalui instrumen tes berbentuk soal uraian sebanyak 5 item. Instrumen tes sebelum digunakan telah diperiksa oleh dua orang pakar yang kemudian dianalisis dengan menggunakan analisis Gregory. Hasil analisis menunjukkan koefisien kesepahaman sebesar 1 yang berarti kedua pakar bersepakat menyatakan instrumen tes secara konstruk layak digunakan.

\section{HASIL DAN PEMBAHASAN}

Skor hasil tes kemampuan memprediksi peserta didik kelas XI MIPA di Kota Makassar diberikan dalam TABEL 1 berikut ini.

Berdasarkan TABEL 1, menunjukkan perolehan skor rata-rata kemampuan peserta didik kelas XI SMA/MA dalam memprediksi berdasarkan grafik secara rata-rata lebih kecil dari setengah skor ideal. Distribusi frekuensi dan pengkategorian kemampuan peserta didik kelas XI SMA dalam memprediksi diberikan dalam TABEL 2.

Berdasarkan TABEL 2, terlihat bahwa frekuensi terbesar berada pada kategori rendah dan tidak ada peserta didik yang skor perolehannya berada pada kategori tinggi dan sangat tinggi. Skor ratarata peroleh peserta didik berdasarkan pengkategorian dalam TABEL 2 berada pada kategori rendah. Hasil ini menunjukkan bahwa kemampuan peserta didik kelas XI di Kota Makassar rendah. Hasil ini bersesuaian dengan hasil penelitian sebelumnya [1] dan [2]. 
TABEL 1. Skor kemampuan peserta didik dalam melakukan prediksi.

\begin{tabular}{cc}
\hline Statistik & Skor Statistik \\
\hline Jumlah Subjek & 103 \\
Skor Maksimum Ideal & 29 \\
Skor Minimum Ideal & 0 \\
Skor Tertinggi & 17 \\
Skor Terendah & 4 \\
Skor Rata-rata & 10,47 \\
Standar Deviasi & 3,21 \\
Variansi & 10,30 \\
\hline
\end{tabular}

TABEL 2. Distribusi frekuensi dan pengkategorian skor kemampuan memprediksi peserta didik dalam fisika.

\begin{tabular}{cccc}
\hline Interval Skor & Kategori & Frekuensi & $\begin{array}{c}\text { Persentase } \\
(\%)\end{array}$ \\
\hline $24-29$ & Sangat Tinggi & 0 & 00,00 \\
$18-23$ & Tinggi & 0 & 00,00 \\
$12-17$ & Sedang & 13 & 12,63 \\
$6-11$ & Rendah & 67 & 65,04 \\
$0-5$ & Sangat Rendah & 23 & 22,33 \\
\hline \multicolumn{4}{c}{ Jumlah } \\
\hline
\end{tabular}

Hasil ini sebenarnya peneliti telah perediksi, namun yang peneliti harapkan berikutnya adalah informasi tentang mengapa hal tersebut dapat terjadi. Hasil penelusuran terhadap peserta didik yang secara skor memiliki skor yang ekstrim. Skor yang ekstrim yang peneliti maksudkan adalah peroleh skor tertinggi dan terendah, adapun datanya adalah terdapat dua orang yang memperoleh skor 17 dan terdapat satu orang dengan skor 4 dan dua orang dengan skor 5. Ke-lima orang inilah yang peneliti sasar untuk mendapatkan informasi. Hasil penelusurannya sebagai berikut;

Pertama, peserta didik tidak mampu mengidentifikasi variabel dengan benar. Variabel yang dimaksud adalah besaran fisis yang ditanyakan dalam soal. Hasil wawancara menunjukkan bahwa peserta didik yang menjawab salah umumnya, tidak mampu mengidentifikasi besaran yang diketahui atau yang ditanyakan dari grafik. Mulai dari simbol, satuan dan cara melafalkannya ada tiga orang yang sama sekali tidak mengetahui simbol dan satuan dari Gaya dan Posisi. Mereka mengingat bahwa itu telah mereka pelajari, namun sudah "lupa". Dibawah ini, satu soal sebagai,

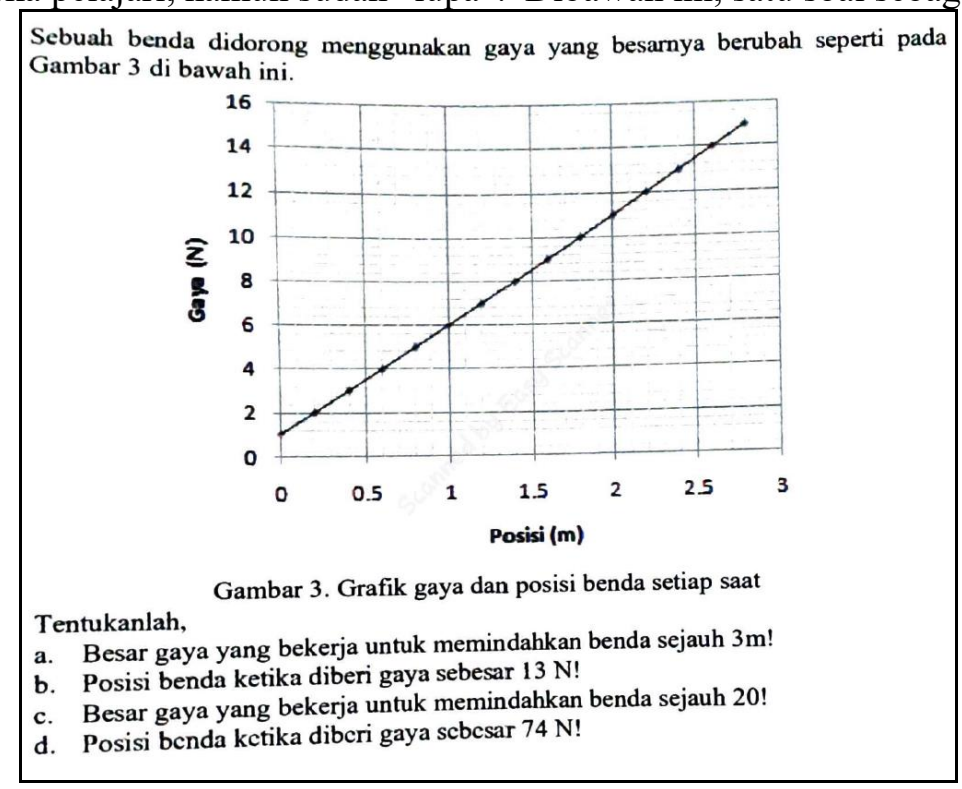

GAMBAR 1. Contoh soal uraian dalam instrumen penelitian. 
Sebagai contoh, ketika disajikan grafik hubungan antara posisi (sumbu $\mathrm{x}$ ) terhadap gaya (sumbu y) di mana pada bagian (a) ditanyakan berapakah gaya jika benda telah berada pada posisi sejauh $3 \mathrm{~m}$, jawabannya merupakan angka yang tidak rasional seperti angka 2 dan lainnya. Mereka menuliskan angka tertentu dimana angka tersebut tidak rasional berada di sumbu y. Hal ini menujukkan bahwa peserta didik tidak mampu mengidentifikasi besaran yang diketahui dan ditanyakan dalam soal. Hal penulis duga disebabkan oleh tidak terbiasanya peserta didik membuat grafik yang dapat diakibatkan oleh tidak terbiasanya mereka dengan aktifivas-aktifitas KPS yang diperoleh dari kegiatan eksperimen atau praktikum dilaboratorium. Hal ini bersuaian dengan hasil wawancara dengan 5 orang dimana peserta didik jarang melakukan praktikum fisika. Jenis praktikum yang telah dilakukan mereka juga tidak ingat. Selain itu, beberapa peserta didik mengalami kesulitan dalam membedakan simbol yang ada pada grafik. Kesalahan dalam menentukan simbol dari besaran menyebabkan peserta didik keliru dalam memprediksi adalah oleh karena, tidak mampu menentukan koordinat titik dari suatu grafik. Ketika diketahui nilai besaran pada sumbu y, maka peserta didik tidak mampu menentukan nilai pasangan besaran ini di sumbu $x$, begitu pula sebaliknya. Hal ini dapat disebabkan oleh kemampuan peserta didik dalam menentukan titik koordinat dua besaran pada grafik lemah. Masalah mendasarnya hamper sama dengan bahasan bagian a masalah pertama. Dalam KPS seharusnya kemampuan ini bias dilatihkan pada bagian mengidentifikasi variabel.

Temuan pertama ini sejalan dengan pendapat Charli dkk [8], faktor yang menyebabkan siswa mengalami kesulitan menyelesaikan soal yang berhubungan dengan menggunakan simbol pada penelitian ini yaitu siswa tidak memahami simbol fisika, siswa tidak mudah dalam mengingat simbol, siswa mengingat simbol dengan cara yang tidak efektif yaitu dengan cara menghafal. Hal ini juga bersesuaian dengan hasil penelitian Nugraha dkk [9], yang mengatakan bahwa kesalahan dalam mengerjakan soal bisa disebabkan menerjemahkan simbol-simbol fisika dan maksud soal, yang disebabkan salah satunya kurang teliti dalam mengerjakan soal fisika. Banyaknya simbol yang digunakan dalam fisika menyebabkan peserta didik sulit untuk membedakan, bahkan ada yang menyamakan simbol variabel dengan simbol satuan. Hasil ini juga sejalan dengan temuan Bektasli dan White [10] yakni salah satu kesalahan yang biasanya dilakukan siswa adalah ketika melihat grafik sebagai gambar, mereka tidak memikirkan variabel pada grafik tersebut.

Kedua, peserta didik tidak mampu menemukan pola untuk memprediksi besaran fisis tertentu dari grafik. Hasil wawancara menunjukkan bahwa peserta didik yang menjawab salah umumnya, tidak memahami cara menentukan kemiringan garis (gradien) berdasarkan grafik. Analisis grafik melalui kemiringan garis, dapat dilakukan dengan mencari besar tangen sudut antara garis (yang menyatakan hubungan antara besaran pada sumbu $\mathrm{x}$ dan sumbu y) dengan garis horizontal pada sumbu x. Gradien ini akan bermanfaat untuk menentukan persamaan matematisnya, oleh karena karena garis yang ditampilkan adalah garis lurus $(y=m x+c)$. Persamaan ini akan menghubungkan variabel pada sumbu X dan sumbu Y, sehingga dengan mengetahui persamaan ini maka variabel yang ditanyakan akan mudah diselesaikan. Dari wawancara diperoleh informasi bahwa analisis seperti ini belum pernah di ajarkan.

Masalah pertama dan kedua sejalan dengan pernyataan Beichner [11] mengenai beberapa kesalahan yang dilakukan peserta didik dalam menjawab soal grafik kinematika, salah satu diantaranya adalah peserta didik sering membaca nilai dari sumbu dan langsung menetapkannya sebagai kemiringan kurva.

Berdasarkan pembahasan sebelumnya, terdapat dua kesulitan mendasar yang dialami oleh peserta didik dalam melakukan prediksi yakni peserta didik tidak mampu mengidentifikasi variabel dengan benar dan peserta didik tidak mampu menemukan pola untuk memprediksi besaran fisis tertentu dari grafik.

Pemaparan tersebut sesuai dengan pernyataan Parmalo dkk [12] dalam penelitiannya yang mengungkap faktor penyebab kesalahan penafsiran memprediksi melaui grafik peserta didik, diantaranya; 1) kemampuan konseptual tentang grafik rendah dan 2) kemampuan spasial siswa rendah. Menurut Ismet [13], kecerdasan spasial dalam pembelajaran berkaitan dengan kemampuan peserta didik dalam membuat hubungan antar konsep, membuat grafik, diagram, peta pikiran dan 
membangun model. Kecerdasan ini dipandang sangat penting bagi keberhasilan pembelajaran. Kedua masalah tersebut berakar dari masalah yang serupa yakni, kemampuan analisis grafik yang tidak ada. $\mathrm{Hal}$ ini wajar oleh karena peserta didik belum pernah diajarkan cara melakukan analisis grafik. Hasil penelusuran tentang kegiatan pembelajaran di sekolah yang menjadi lokasi penelitian, penulis memperoleh informasi jika peserta didik yang menjadi subjek penelitian belum pernah praktikum yang didalamnya terdapat aktivitas yang menuntut kemampuan menganalisis grafik.

\section{SIMPULAN}

Berdasarkan hasil dan pembahasan maka dapat disimpulkan bahwa skor rata-rata kemampuan peserta didik memprediksi dalam fisika kelas XI SMA/MA di kota berada pada kategori rendah.

\section{REFERENSI}

[1] H. Anis and A. M. Yusuf, "Pembelajaran Fisika Berbasis Keterampilan Proses Sains pada Topik Listrik Arus Searah," Vidya Karya, vol. 21, no. 2, 2017.

[2] E. H. Sujiono, B. Jabu and M. N. Zakaria, "Pemetaan Hasil Ujian Nasional Tingkat SMA/MA di Kabupaten Jeneponto dan Takalar Provinsi Sulawesi Selatan Tahun 2010," Lembaga Penelitian UNM, Makassar, 2012.

[3] B. Subali, D. Rudiana, H. Firman and I. Kaniawati, "Analisis Kemampuan Interpretasi Grafik Kinematika pada Mahasiswa Calon Guru Fisika," in Prosiding Simposium Nasional Inovasi dan Pembelajaran Sains, Bandung, p.269-272, 2015.

[4] N. Gültepe, "Reflections on high school students' graphing skills and their conceptual understanding of drawing chemistry graphs.," in Theory \& Practice Sec.16, Educational Sciences, 2016, p. 53-81.

[5] Y. Christian, Solikhin and B. A. Nugroho, "Interpretasi Mahasiswa Tentang Garfik Kinematika.," in Prosiding Seminar Nasional Penelitian, Pendidikan, dan Penerapan MIPA Fakultas MIPA Universitas Negeri Yogyakart, Yogyakarta, p. 105-108., 2009.

[6] H. G. Petrova, "Developing Students' Graphic Skills in Physics Education at Secondary School.," IOSR Journal of Research \& Method in Education, vol. 6, no. 5, pp. 123-126, 2016.

[7] M. S. Uzun, N. Sezen and A. Bulbul, "Investigating Students' Abilities Related to Graphing Skill," in Social and Behavioral Sciences, 46, 2942-2946, 2012.

[8] L. Charli, A. Amin and D. Agustina, "Kesulitan Siswa dalam Menyelesaikan Soal Fisika pada Materi Suhu dan Kalor di Kelas X SMA Ar-Risalah Lubuklinggau Tahun Pelajaran 2016/2017," Journal of Education and Instruction (JOEAI), vol. 1, no. 1, p. 42-50., 2018.

[9] A. Nugraha, Darsikin and S. Saehana, "esulitan Siswa dalam Menyelesaikan Permasalahan Grafik Kinematika.," Jurnal Inovasi dan Pembelajaran Fisika, vol. 4, no. 1, pp. 77-88, 2017.

[10] B. Bektasli and A. L. White, "The Relationship Between Logical Thinking, Gender, and Kinematics Graph Interpretation Skills.," Egitim Arastirmalari - Eurasian Journal of Educational Research, vol. 48, pp. 1-20, 2012.

[11] R. J. Beichner, "Testing Student Interpretation of Kinematic Graphs.," American Journal of Physics,, vol. 62, no. 8, pp. 750-762, 1994.

[12] Y. Parmalo, T. Djudin and E. Oktavianty, "Deskripsi Kemampuan Menafsirkan Grafik Kinematika Siswa Kelas X SMA Negeri 3 Sungai Kakap," Jurnal Pendidikan dan Pembelajaran, vol. 5, no. 7, pp. 1-16, 2016.

[13] Ismed, "Dampak Program Perkuliahan Mekanika Berbasis Multipel Representasi Terhadap Kecerdasan Spasial Mahasiswa Calon Guru," Jurnal Pendidikan Fisika Indonesia, vol. 9, pp. 132-143., 2013. 